\title{
Productive leaf functional traits of Chinese savanna species
}

\author{
Jiao-Lin Zhang $\cdot$ L. Poorter $\cdot$ Kun-Fang Cao
}

Received: 21 January 2012/ Accepted: 11 July 2012/Published online: 27 July 2012

(C) Springer Science+Business Media B.V. 2012

\begin{abstract}
The river valleys in Southwest China are characterized by a dry-hot climate and relatively rich soils, and host valley-type savannas that are dominated by deciduous species. However, little is known about the ecological adaptations of Chinese savanna plants to the local environments. We hypothesize that Chinese savanna species mainly possess a droughtavoiding strategy by having a deciduous leaf habit and have productive leaf traits. To test this hypothesis, we measured 26 anatomical, morphological, physiological, and chemical traits for 33 woody species from a valley savanna in Southwest China and compared them with the literature data of other dry and wet tropical tree species and a global dataset. We found
\end{abstract}

Electronic supplementary material The online version of this article (doi:10.1007/s11258-012-0103-8) contains supplementary material, which is available to authorized users.

J.-L. Zhang · K.-F. Cao ( $ه)$

Key Laboratory of Tropical Forest Ecology,

Xishuangbanna Tropical Botanical Garden, Chinese

Academy of Sciences, Mengla 666303, Yunnan, China

e-mail: caokf@xtbg.ac.cn

L. Poorter

Forest Ecology and Forest Management Group,

Wageningen University, P.O. Box 47,

6700 AA Wageningen, The Netherlands

K.-F. Cao

Yuanjiang Dry-Hot-Valley Ecological Station,

Xishuangbanna Tropical Botanical Garden, Chinese

Academy of Sciences, Yuanjiang 653300, Yunnan, China that Chinese savanna species showed drought avoidance adaptations and exhibited productive leaf traits, such as thin and dense leaves with high ratio of palisade to spongy mesophyll, leaf nutrient concentrations and photosynthetic capacity. Correlations of photosynthetic capacity with $\mathrm{N}, \mathrm{P}$, and stomatal conductance across Chinese savanna species were consistent with global patterns reported for seed plants. However, the Chinese savanna species had consistently greater carbon gain at a given specific leaf area, N, P, and stomatal conductance, suggesting higher nutrient- and intrinsic water use efficiencies. These results suggest that paradoxically, Chinese savanna species are adapted to the stressful dry-hot valley habitat by having productive leaves.

Keywords Adaptation - Leaf functional traits . Productivity $\cdot$ Resource use efficiency $\cdot$ Savanna

\section{Introduction}

Globally and locally, drought is one of the most important environmental drivers of species growth, survival, and distribution (e.g., Toledo et al. 2012), and ecosystem productivity (Running et al. 2004). Climate models predict that global climate change will result in regionally strong reduction in rainfall and increased dry season length (IPCC 2007). Insight into ecological strategies of plants' adaptation to drought will provide a better idea of how plants respond to climate change. 
In general, two types of plant drought-adaptation strategies can be distinguished: plants can be adapted to drought by being drought avoidant, or by being physiologically drought tolerant. Drought-avoiding species can enhance water uptake by having more or deeper roots, or they may reduce water loss from leaves by reducing leaf area, and the stomatal and cuticular conductance, or by shedding their leaves in the dry season (e.g., Clifford et al. 1998; Balaguer et al. 2002; Zhang et al. 2007; Markesteijn and Poorter 2009). Drought-tolerant species have physiological adaptations that permit continued water transport, gas exchange, or cell survival at low water status (e.g., Zhang et al. 2007; Markesteijn et al. 2011). Osmotic adjustment (involving inorganic ions, carbohydrates, and organic acids) and changes in cellular/tissue elasticity (i.e., bulk elastic modulus), are associated with drought tolerance (e.g., Clifford et al. 1998; Balaguer et al. 2002).

Carbon and nutrient investments in stress resistance (such as resistance to drought) are realized at the expense of plant growth (Reich et al. 1997; Wright et al. 2004, 2005). As a consequence, there is a trade-off between stress resistance and productivity across species (Grime 1977; Grime et al. 1997). These different resource use strategies are also reflected in leaf traits and trade-offs (Reich et al. 1997, 1999). At the global scale there is, across species, a positive correlation between specific leaf area, leaf nitrogen and phosphorus concentrations, and photosynthetic capacity. This "leaf economics spectrum" runs from species with short-lived, productive leaves with quick returns on carbon and nutrient investments to species with long-lived resistant leaves with slow returns on resource investments (Wright et al. 2004). Such a spectrum is also found within local plant communities, although in some cases, plants may be positioned at one side of the leaf economics spectrum. For example, alpine meadow species from the Tibetan Plateau were positioned at the productive side of the specific leaf area-photosynthetic capacity axis (He et al. 2006). Recent studies also indicate that the proportionality of scaling relationships between leaf trait pairs is similar across sites, but the intercepts do vary (Reich et al. 1997, 1999). For example, Australian plant communities from drier sites had higher intercepts for their relationship between photosynthetic capacity and stomatal conductance (Wright et al. 2001), indicating higher intrinsic water use efficiency of plants in drier sites.
Due to the rain-shadow effect of mountains, the river valleys in Southwest China are characterized by a dry-hot climate and host the valley-type savannas, which are dominated by deciduous woody species with canopy height of 4-6 m (Wu 1995; Jin and Ou 2000). However, little is known about the ecological adaptation of plants from these Chinese savannas (e.g., Zhang et al. 2007; Zhu et al. 2009). Here, we evaluated functional leaf traits for 33 woody species from a dry valley savanna in Southwest China. We selected 26 anatomical, morphological, physiological, and chemical traits that are important for the carbon, water and nutrient economy of plants, and compared them with the literature data of other tropical tree species and a global dataset (Wright et al. 2004).

We addressed the following questions: (1) Do Chinese savanna species employ specific droughtadaptation strategies compared with other tropical tree species adapted to dry savannas or to wet rainforests? (2) Where are Chinese savanna species positioned along the global leaf economics spectrum? We hypothesize that Chinese savanna species mainly possess (1) a droughtavoiding strategy by having a deciduous leaf habit and, as a consequence, have (2) productive leaf traits. There are three justifications for this hypothesis. First, Chinese savannas are dominated by deciduous species, in contrast to American and Australian savannas which are dominated by evergreens (e.g., Bowman and Prior 2005). Second, deciduous species possess productive leaf traits (such as higher nutrient concentrations and photosynthetic capacity) compared to evergreen species because deciduous species are only physiologically active in the favorable wet season so that they must compensate for a shorter growing season by having productive traits (e.g., Eamus and Prichard 1998; Givnish 2002). Third, Chinese savanna soils are relatively nutrient-rich, compared to Australian, African, and American savanna soils (Table S1), which permits them to have a deciduous leaf habit as lost nutrients can easily be replaced and to employ a productive strategy with high nutrient concentrations.

\section{Materials and methods}

Site and species

This study was conducted in a savanna of the Yuan River $\left(23^{\circ} 41^{\prime} \mathrm{N}, 101^{\circ} 59^{\prime} \mathrm{E}\right.$, altitude $\left.770 \mathrm{~m}\right), 200 \mathrm{~km}$ 
south of Kunming, Yunnan, Southwest China. Mean annual temperature is $23.8{ }^{\circ} \mathrm{C}$, with a monthly mean temperature ranging from $16.8{ }^{\circ} \mathrm{C}$ in the coldest month to $28.7^{\circ} \mathrm{C}$ in the hottest month. The temperature in Chinese savannas is therefore intermediate compared to other tropical savannas (Table S1). Mean annual precipitation is $802 \mathrm{~mm}$, which is lower than that of other tropical savannas $(1,000-1,700 \mathrm{~mm})$. The dry climate is due to the strong evapotranspiration (Penman evaporation $>1,566 \mathrm{~mm}$ ) in combination with a pronounced 6-month dry season (NovemberApril). The soil is a ferralic cambisol, containing moderate organic matter, higher $\mathrm{N}, \mathrm{P}, \mathrm{K}, \mathrm{Ca}$, and $\mathrm{Mg}$ concentrations, lower cation exchange capacity and moderate $\mathrm{pH}$ value, compared to soils of other tropical savannas (Table $\mathrm{S} 1$ ).

The vegetation is dominated by deciduous shrub species, such as (listed in decreasing order of abundance) Phyllanthus emblica, Lannea coromandelica, Woodfordia fruticosa, Terminthia paniculata, and Vitex negundo. Coexisting evergreen species include Pistacia weinmannifolia, Osteomeles schwerinae, Olea cuspidate, and Carissa spinarum. This vegetation has been protected since 1980s but has occasionally been disturbed by grazing.

We selected 33 woody species for the study, representing ca. $80 \%$ of the woody savanna flora in this region (Table S2). The study species include 23 tree species, eight shrub species, and two liana species, with 17 species being winter deciduous (leaf fall during November-February), six drought deciduous (leaf fall during March-April), and ten evergreen species. During the late dry season, seven species flush leaves and ten species have shoot dieback.

Leaf morphology and anatomy

We sampled leaves from 21 species for the analyses of leaf anatomy. Five current-year mature sunlit leaves from each of six plants per species were harvested in the rainy season and sealed in plastic bags, and the leaf anatomy was immediately determined in a field lab near the site. Hand-cut transverse sections were taken from middle-lamina sections, avoiding the midribs. We measured the thickness of upper and lower epidermises, palisade and spongy mesophylls under a compound microscope with $10 \times$ and $40 \times$ objectives calibrated with an ocular micrometer, averaged from five fields of the same lamina section for each leaf. Stomatal density (SD; in $\mathrm{mm}^{-2}$ ) and guard cell length (GCL; in $\mu \mathrm{m}$ ) were measured for epidermal prints made with colorless nail varnish. When necessary, epidermal trichomes were removed by brushing to recognize the stomata. Stomatal pore area index (SPI) was calculated as SD $\times \mathrm{GCL}^{2}$ (Sack et al. 2003).

Leaf width (LW; in $\mathrm{cm}$ ), length ( $\mathrm{LL}$; in $\mathrm{cm})$, and area (LA; in $\mathrm{cm}^{2}$ ) were measured for 30-190 simple leaves or leaflets of compound leaves from 10 to 20 individuals per species using a portable leaf area meter (LI-3000A, LI-COR, Nebraska, USA). Leaflets were considered to be functionally equivalent to simple leaves (e.g., Warman et al. 2011). The petiole was excluded from the leaf area measurements. Leaf samples were then oven-dried at $80{ }^{\circ} \mathrm{C}$ for $48 \mathrm{~h}$. Leaf thickness (LT; in $\mu \mathrm{m}$ ) was measured for the hand-cut transverse sections with a microscope. From these measurements, we calculated the following morphological traits: leaf slenderness $(\mathrm{LS}=\mathrm{LL} / \mathrm{LW})$, specific leaf area (SLA $=$ LA/leaf dry mass; in $\mathrm{cm}^{2} \mathrm{~g}^{-1}$ ), and leaf density $\left(\mathrm{LD}=1 /[\mathrm{SLA} \times \mathrm{LT}]\right.$; in $\left.\mathrm{kg} \mathrm{m}^{-3}\right)$.

\section{Leaf nutrients}

Dry leaf samples were pulverized to pass a 60-mesh sieve (hole diameter $=0.25 \mathrm{~mm}$ ), digested with $\mathrm{H}_{2} \mathrm{SO}_{4}$, and then the $\mathrm{N}$ concentration (in $\mathrm{mg} \mathrm{g}^{-1}$ ) was determined with an auto Kjeldahl unit (K370, BÜCHI Labortechnik AG, Flawil, Switzerland). After leaf samples were digested with concentrated $\mathrm{HNO}_{3}-\mathrm{HCLO}_{4}$, foliar concentrations of $\mathrm{P}, \mathrm{K}, \mathrm{Ca}$, and $\mathrm{Mg}$ (all in $\mathrm{mg} \mathrm{g}^{-1}$ ) were analyzed with an inductively coupled plasma atomicemission spectrometer (IRIS Advantage-ER, Thermo Jarrell Ash Corporation, Massachusetts, USA).

\section{Photosynthesis}

Gas exchange was measured from a newly mature leaf or leaflet from each of four to five plants of 24 species between 0800 and $1,030 \mathrm{~h}$ using a portable infrared gas analyzer (LI-6400, LI-COR, Nebraska, USA). A photosynthetic photon flux density of $1,500 \mu \mathrm{mol} \mathrm{m}{ }^{-2} \mathrm{~s}^{-1}$ was provided to the leaf surface by an integrated red blue light source. The $\mathrm{CO}_{2}$ concentration inside the leaf chamber was maintained at $380 \mu \mathrm{mol} \mathrm{mol}{ }^{-1}$. The relative air humidity inside the leaf chamber was 60-65\%, leaf temperature was $28-30^{\circ} \mathrm{C}$, and leaf to air vapor pressure deficit was $1.0-1.2 \mathrm{kPa}$. Stomatal conductance per area $\left(g_{\mathrm{s}}\right.$; in mol m $\left.\mathrm{m}^{-2} \mathrm{~s}^{-1}\right)$ and maximal 
photosynthetic rate per area $\left(A_{\mathrm{a}}\right.$; in $\left.\mu \mathrm{mol} \mathrm{m} \mathrm{m}^{-2} \mathrm{~s}^{-1}\right)$ were obtained from the gas exchange measurements.

Nutrient and water use efficiencies

Photosynthetic N (PNUE; in $\mu \mathrm{mol} \mathrm{mol}{ }^{-1} \mathrm{~s}^{-1}$ ) and P use efficiencies (PPUE; in mmol mol ${ }^{-1} \mathrm{~s}^{-1}$ ) were calculated as the ratios of mass-based maximum photosynthetic rate $\left(A_{\mathrm{m}}\right.$; in $\left.\mathrm{nmol} \mathrm{g}^{-1} \mathrm{~s}^{-1}\right)$ to foliar $\mathrm{N}$ and $\mathrm{P}$ concentrations, respectively.

Intrinsic water use efficiency (WUE $\mathrm{W}_{\mathrm{i}}$ in $\mu \mathrm{mol} \mathrm{mol}{ }^{-1}$ ) was calculated as $A_{\mathrm{a}} / g_{\mathrm{s}}$. We used $\delta^{13} \mathrm{C}$ (in \%o) of the leaf as a proxy for long-term $\mathrm{WUE}_{\mathrm{i}}$ (Farquhar et al. 1989). Leaves from the same adult trees measured for gas exchange were used for $\delta^{13} \mathrm{C}$ analysis. Leaves were washed with deionized water, dried at $60{ }^{\circ} \mathrm{C}$ and then pulverized to pass the 60 -mesh sieve. Foliar $\delta^{13} \mathrm{C}$ was analyzed with a elemental analyzer (Flash EA 1112, Thermo Electron Corporation, Massachusetts, USA) interfaced to an isotope ratio mass spectrometer

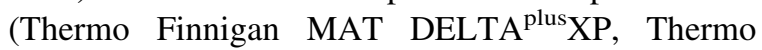
Electron Corporation, Massachusetts, USA).

$\delta^{13} \mathrm{C}=\left(R_{\text {sample }}-R_{\text {standard }}\right) / R_{\text {standard }} \times 1000$

where $R_{\text {sample }}$ and $R_{\text {standard }}$ were the ratios of ${ }^{13} \mathrm{C} /{ }^{12} \mathrm{C}$ in the sample and in the Pee Dee Belemnite standard, respectively. Standard glycine and cellulose measurements for every 15-20 samples were used to check the accuracy of the analysis $( \pm 0.19 \%$ ).

Statistical analysis

Before analysis, all data were $\log _{10}$-transformed to satisfy the assumptions of normality and homoscedasticity. Associations of 22 key traits were analyzed with a principal component analysis (PCA; Table S3). Thickness of upper and lower epidermis plus cuticle, palisade and spongy mesophylls was not included in PCA analysis because of their collinearity with leaf thickness. To evaluate whether Chinese savanna species have a typical drought-resistant strategy, we compared their leaf traits with traits of other tropical woody species using a dataset compiled from the literature (Dataset S1). We compared Chinese savanna species (33 species) with other typical woody species from dry savannas (80 species) where the climate is similar to Chinese savanna and species from wet rainforests (195 species). Differences in mean trait values were analyzed using one-way analysis of variance (ANOVA), with vegetation type as a factor. Pairwise differences between vegetation types were analyzed with a $t$ test.

To determine whether the associations between key leaf traits across Chinese savanna species are different from the global patterns, we compared the leaf economics-spectrum traits of our study species with those of GLOPNET species (Wright et al. 2004). Bivariate relationships were analyzed with Pearson's correlation and with standardized major axis (SMA) regression. SMA analysis is appropriate when the purpose of line-fitting is to summarize the relationships between two variables that are subject to errors, as in many allometric studies (e.g., Wright et al. 2004). The computer package SMATR (Warton et al. 2006) was used to examine the differences in SMA slopes, intercepts or shifts along the common slopes between our dataset and the global dataset (Wright et al. 2004).

\section{Results}

Photosynthetic capacity

Chinese savanna species had an average $g_{\mathrm{s}}$ of $0.225 \mathrm{~mol} \mathrm{~m}^{-2} \mathrm{~s}^{-1}, A_{\mathrm{a}}$ of $13.0 \mu \mathrm{mol} \mathrm{m} \mathrm{s}^{-2}$, and $A_{\mathrm{m}}$ of $127 \mathrm{nmol} \mathrm{g}^{-1} \mathrm{~s}^{-1}$ (Table 1). They had a significantly higher $A_{\mathrm{m}}$ as compared to other tropical savanna species $\left(104 \mathrm{nmol} \mathrm{g}^{-1} \mathrm{~s}^{-1}\right)$, and had comparable $A_{\mathrm{m}}$ to tropical rainforest species $\left(125 \mathrm{nmol} \mathrm{g}^{-1} \mathrm{~s}^{-1}\right)$.

Leaf structures and their associations

Chinese savanna species had different leaf characteristics compared to savanna and rainforest species (Table 1). They had, for example, better-developed palisade mesophylls as indicated by considerably higher ratio of palisade to spongy mesophyll (1.27 vs. 0.75 ), and high stomatal density (496 vs. 422 stomata $\mathrm{mm}^{-2}$ ) compared to rainforest species. Chinese savanna species had a higher leaf density compared to savanna and rainforest species (being 480 for Chinese savanna, 392 for other savanna, and $412 \mathrm{~kg} \mathrm{~m}^{-3}$ for rainforest species), but a statistically similar leaf area (Table 1). Chinese savanna species had statistically similar epidermis thickness, guard cell length and leaf slenderness compared to rainforest species.

Leaf trait associations of the Chinese savanna species were analyzed with a PCA (Fig. 1; Table S3). 
Table 1 Mean \pm SE (numbers of species measured) for traits of Chinese savanna, other tropical savanna and lowland rainforest species

\begin{tabular}{|c|c|c|c|c|c|c|}
\hline Trait & Code & Unit & Chinese savanna & $\begin{array}{l}\text { Other tropical } \\
\text { savannas }\end{array}$ & $\begin{array}{l}\text { Lowland tropical } \\
\text { rainforest }\end{array}$ & $P$ \\
\hline \multicolumn{7}{|l|}{ Anatomy and morphology } \\
\hline $\begin{array}{l}\text { Thickness of upper epidermis } \\
\text { and cuticle }\end{array}$ & TUE & $\mu \mathrm{m}$ & $30.0 \pm 2.4(21)$ & & $27.5 \pm 1.2(166)$ & ns \\
\hline Thickness of palisade mesophyll & $\mathrm{TP}$ & $\mu \mathrm{m}$ & $96 \pm 7(21)$ & & $73 \pm 3(166)$ & $* *$ \\
\hline Thickness of spongy mesophyll & $\mathrm{TS}$ & $\mu \mathrm{m}$ & $86 \pm 11(21)$ & & $119 \pm 6(166)$ & $*$ \\
\hline Thickness of lower epidermis & TLE & $\mu \mathrm{m}$ & $16.3 \pm 1.1(21)$ & & $15.6 \pm 0.5(166)$ & ns \\
\hline $\begin{array}{l}\text { Ratio of palisade to spongy } \\
\text { mesophyll }\end{array}$ & RPS & & $1.27 \pm 0.09(21)$ & & $0.75 \pm 0.03$ & $* * *$ \\
\hline Stomatal density & SD & $\mathrm{mm}^{-2}$ & $496 \pm 54(21)$ & & $422 \pm 45(81)$ & ns \\
\hline Guard cell length & GCL & $\mu \mathrm{m}$ & $20.8 \pm 1.4(21)$ & & $20.4 \pm 0.8(81)$ & ns \\
\hline $\begin{array}{l}\text { Stomatal pore area index } \\
\left(=\mathrm{SD} \times \mathrm{GCL}^{2}\right)\end{array}$ & SPI & & $0.190 \pm 0.018$ & & $0.135 \pm 0.009(81)$ & $* *$ \\
\hline Leaf area & LA & $\mathrm{cm}^{2}$ & $56.6 \pm 10.3(22)$ & $76.7 \pm 13.3(23)$ & $69.6 \pm 11.5(174)$ & ns \\
\hline $\begin{array}{l}\text { Leaf slenderness } \\
\text { (=leaf length/leaf width) }\end{array}$ & LS & & $2.45 \pm 0.18$ & & $3.09 \pm 0.32(84)$ & ns \\
\hline Leaf thickness & LT & $\mu \mathrm{m}$ & $232 \pm 16(27) b$ & $311 \pm 22(23) \mathrm{a}$ & $239 \pm 8(166) b$ & $* *$ \\
\hline Leaf density $(=1 /[\mathrm{SLA} \times \mathrm{LT}])$ & LD & $\mathrm{kg} \mathrm{m}^{-3}$ & $480 \pm 22(27) \mathrm{a}$ & $392 \pm 14(23) b$ & $412 \pm 13(77) b$ & $*$ \\
\hline Specific leaf area & SLA & $\mathrm{cm}^{2} \mathrm{~g}^{-1}$ & $100 \pm 4(27) b$ & $89 \pm 5(72) c$ & $130 \pm 6(106) \mathrm{a}$ & $* * *$ \\
\hline \multicolumn{7}{|l|}{ Nutrients } \\
\hline Nitrogen & $\mathrm{N}$ & $\mathrm{mg} \mathrm{g}^{-1}$ & $17.6 \pm 0.8(21) \mathrm{a}$ & $15.1 \pm 1.1(37) b$ & $18.3 \pm 0.5(106) \mathrm{a}$ & $* * *$ \\
\hline Phosphorus & $\mathrm{P}$ & $\mathrm{mg} \mathrm{g}^{-1}$ & $1.16 \pm 0.08(21) \mathrm{b}$ & $0.92 \pm 0.10(24) \mathrm{c}$ & $1.28 \pm 0.04(105) \mathrm{a}$ & $* * *$ \\
\hline $\mathrm{N} / \mathrm{P}$ ratio & $\mathrm{N} / \mathrm{P}$ & & $16.0 \pm 0.7(21) \mathrm{ab}$ & $18.6 \pm 0.7(24) \mathrm{a}$ & $15.3 \pm 0.4(105) \mathrm{b}$ & $* *$ \\
\hline Potassium & $\mathrm{K}$ & $\mathrm{mg} \mathrm{g}^{-1}$ & $10.7 \pm 0.7(21)$ & & $9.6 \pm 0.4(106)$ & ns \\
\hline Calcium & $\mathrm{Ca}$ & $\mathrm{mg} \mathrm{g}^{-1}$ & $13.6 \pm 2.1(21)$ & & & \\
\hline Magnesium & $\mathrm{Mg}$ & $\mathrm{mg} \mathrm{g}^{-1}$ & $2.57 \pm 0.3(21)$ & & & \\
\hline \multicolumn{7}{|l|}{ Photosynthesis } \\
\hline Stomatal conductance & $g_{\mathrm{s}}$ & $\mathrm{mol} \mathrm{m}^{-2} \mathrm{~s}^{-1}$ & $0.225 \pm 0.014(24) \mathrm{b}$ & $0.293 \pm 0.027(4) \mathrm{ab}$ & $0.337 \pm 0.026(38) \mathrm{a}$ & $*$ \\
\hline $\begin{array}{l}\text { Maximum photosynthetic } \\
\text { rate per area }\end{array}$ & $A_{\mathrm{a}}$ & $\mu \mathrm{mol} \mathrm{m}{ }^{-2} \mathrm{~s}^{-1}$ & $13.0 \pm 0.5(24)$ & $12.1 \pm 0.4(62)$ & $12.4 \pm 0.6(38)$ & ns \\
\hline $\begin{array}{l}\text { Maximum photosynthetic } \\
\text { rate per mass }\end{array}$ & $A_{\mathrm{m}}$ & $\mathrm{nmol} \mathrm{g}^{-1} \mathrm{~s}^{-1}$ & $127 \pm 8(23) \mathrm{a}$ & $104 \pm 6(62) b$ & $125 \pm 10(38) \mathrm{a}$ & $*$ \\
\hline \multicolumn{7}{|l|}{ Photosynthetic nutrient use efficiency } \\
\hline Photosynthetic $\mathrm{N}$ use efficiency & PNUE & $\mu \mathrm{mol} \mathrm{mol}{ }^{-1} \mathrm{~s}^{-1}$ & $105 \pm 6(16) \mathrm{a}$ & $116 \pm 7(37) \mathrm{a}$ & $86 \pm 5(38) b$ & $* * *$ \\
\hline Photosynthetic P use efficiency & PPUE & $\mathrm{mmol} \mathrm{mol}^{-1} \mathrm{~s}^{-1}$ & $3.71 \pm 0.17$ (17)ab & $4.06 \pm 0.26(24) \mathrm{a}$ & $3.23 \pm 0.16(38) b$ & $*$ \\
\hline \multicolumn{7}{|l|}{ Water use efficiency } \\
\hline $\begin{array}{l}\text { Intrinsic water use efficiency } \\
\left(A_{\mathrm{a}} / g_{\mathrm{s}}\right)\end{array}$ & WUE $_{\mathrm{i}}$ & $\mu \mathrm{mol} \mathrm{mol}{ }^{-1}$ & $62.3 \pm 2.6(24) \mathrm{a}$ & $19.0 \pm 3.0(4) \mathrm{c}$ & $42.0 \pm 2.1(38) b$ & $* * *$ \\
\hline Carbon isotope composition $^{\mathrm{a}}$ & $\delta^{13} \mathrm{C}$ & $\%$ & $-27.8 \pm 0.2(12) \mathrm{a}$ & $-28.9 \pm 0.4(8) b$ & $-33.1 \pm 1.8(226) \mathrm{c}$ & $* * *$ \\
\hline
\end{tabular}

Traits were compared among or between species groups using one-way ANOVA or $t$ test when data available. Mean followed by different letters are statistically different. See Dataset $\mathrm{S} 1$ for species-level mean values of each trait

ns $P>0.05$; $P<0.05$; ** $P<0.01$; *** $P<0.001$

${ }^{\text {a }}$ Data on $\delta^{13} \mathrm{C}$ values for tropical rainforest tree species were from Qu et al. (2001)

The first two axes of PCA explained, respectively, 37.4 and $29.4 \%$ of the variance. The trait loadings on the first axis were primarily related to gas exchange and resource use efficiencies. The trait loadings on the second axis were related to leaf morphology, nutrient concentrations, and anatomy.

Across Chinese savanna species, the ratio of palisade to spongy mesophyll and the stomatal density were 


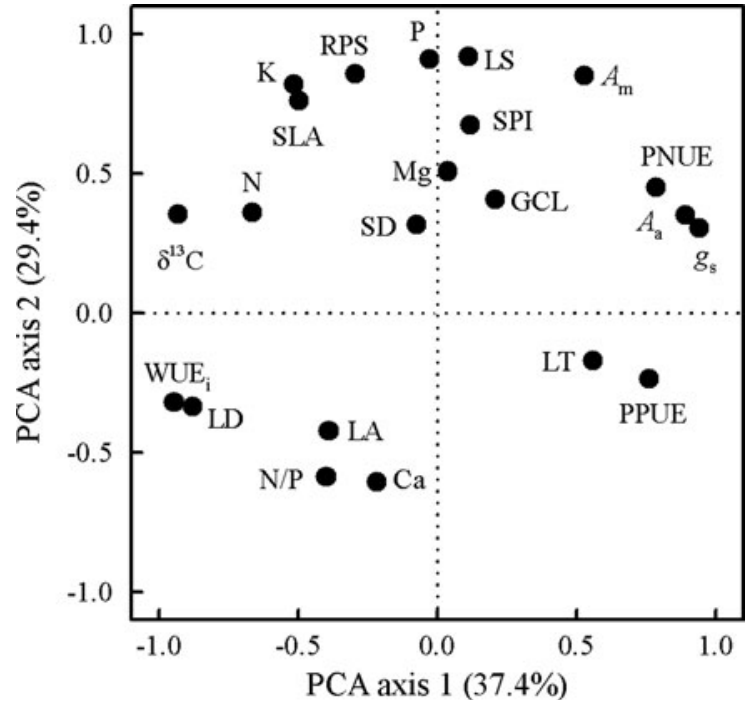

Fig. 1 Principal component analysis for 22 traits of 33 Chinese savanna woody species. Trait codes, eigenvectors and correlations between traits were shown in Table 1, Table S3 and Table $\mathrm{S} 4$, respectively. All variables were $\log _{10}$-transformed prior to analysis

positively correlated with leaf density, whereas guard cell length was negatively correlated with leaf density (Fig. 2). Guard cell length was negatively correlated with stomatal density (Table S4). Correlation analyses revealed that $\mathrm{N}$ and $A_{\mathrm{m}}$ were positively correlated with leaf density for the Chinese savanna species, but negatively correlated across Australian savanna species (Fig. 3). The associations of SLA with $\mathrm{N}$ and $\mathrm{P}$ across Chinese savanna species are consistent with those for GLOPNET species (Fig. 4; Table 2).

Resource use efficiencies

Our analysis showed that Chinese savanna species had high resource use efficiencies. Average PNUE (105 $\mu \mathrm{mol} \mathrm{mol}{ }^{-1} \mathrm{~s}^{-1}$ ) and PPUE (3.71 $\mathrm{mmol} \mathrm{mol}^{-1} \mathrm{~s}^{-1}$ ) were statistically similar to those of other tropical savanna species (PNUE: $116 \mu \mathrm{mol} \mathrm{mol}^{-1} \mathrm{~s}^{-1}$; PPUE: $\left.4.06 \mathrm{mmo} ; \mathrm{mol}^{-1} \mathrm{~s}^{-1}\right)$, but higher than those of tropical rainforest species (PNUE: $86 \mu \mathrm{mol} \mathrm{mol}^{-1} \mathrm{~s}^{-1}$; PPUE: $3.23 \mathrm{mmol} \mathrm{mol}^{-1} \mathrm{~s}^{-1}$; Table 1). Slopes for $A_{\mathrm{m}}$ versus $\mathrm{N}$ and $A_{\mathrm{m}}$ versus $\mathrm{P}$ did not differ significantly between Chinese savanna and GLOPNET species, but Chinese savanna species had higher intercepts, indicating that they have higher photosynthetic nutrient use efficiency (Fig. 5; Table 2). Chinese savanna species had higher $\delta^{13} \mathrm{C}$ than species from either other

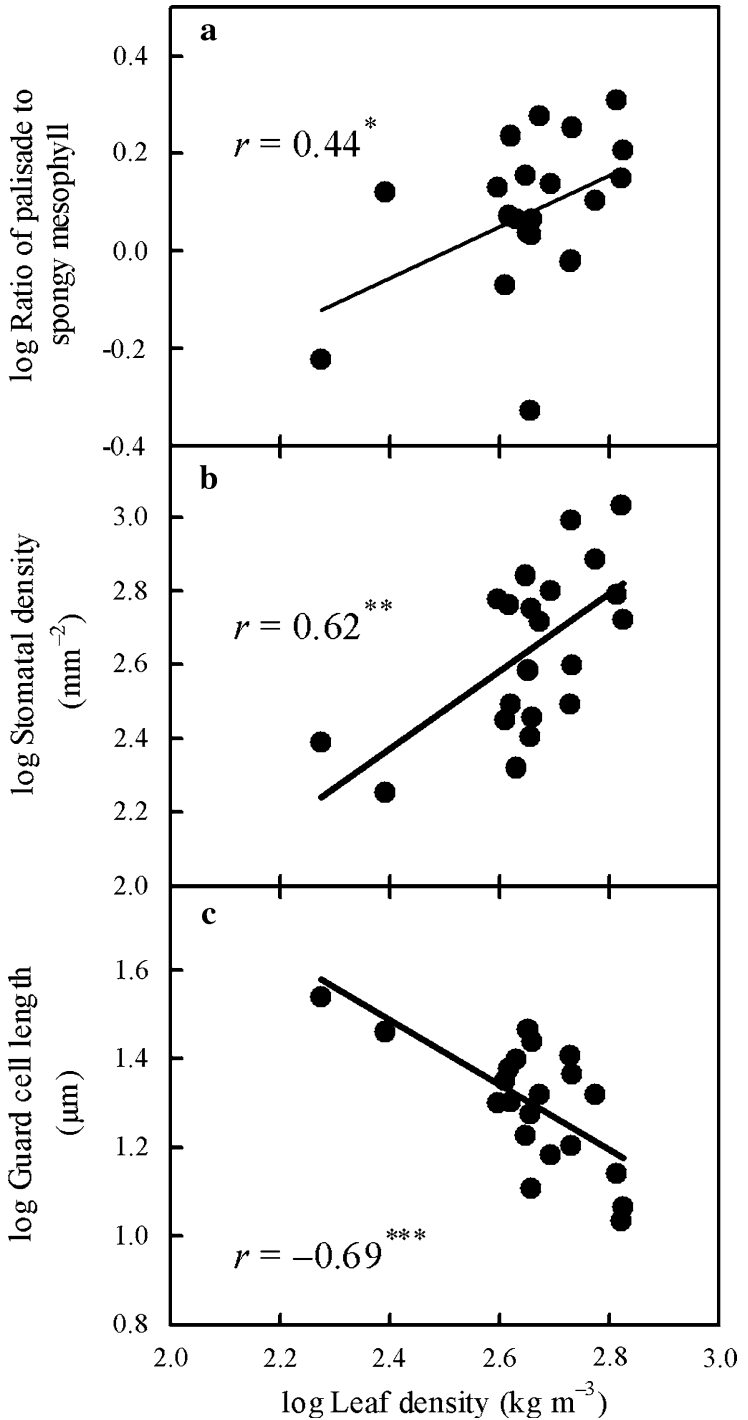

Fig. 2 Leaf density in relation to a ratio of palisade to spongy mesophyll, b stomatal density, and $\mathbf{c}$ guard cell length across Chinese savanna species. $* P<0.05$; $* * P<0.01$; $* * * P<0.001$

savannas or rainforests (Table 1). In line with this, Chinese savanna species had higher intrinsic water use efficiency than GLOPNET species (Fig. 6).

\section{Discussion}

Chinese savanna species are productive

We tested the hypothesis that Chinese savanna species have productive leaf traits because of their deciduous leaf habit and relatively fertile soil conditions of their 


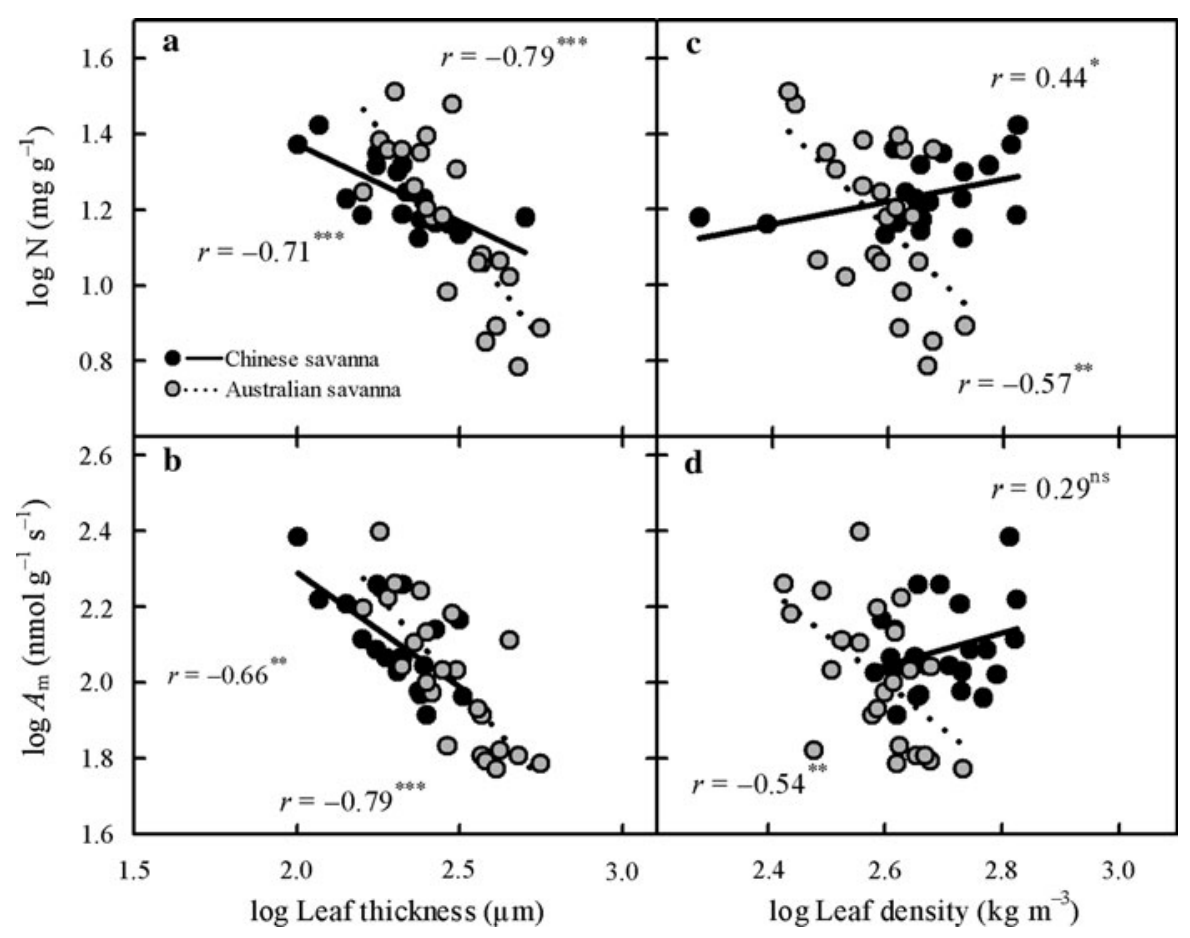

Fig. 3 Leaf thickness and leaf density in relation to $\mathbf{a}, \mathbf{c}$ foliar $\mathrm{N}$ concentration and $\mathbf{b}, \mathbf{d}$ maximum photosynthetic rate per mass $\left(A_{\mathrm{m}}\right)$ across Chinese and Australian savanna species. $n s P>0.05 ; * P<0.05 ; * * P<0.01 ; * * * P<0.001$

habitat. We indeed found that they had (1) higher photosynthetic capacity compared to other tropical woody savanna species (Table 1), (2) higher photosynthetic capacity and photosynthetic nutrient use efficiencies compared to a global dataset (Table 2), and (3) are situated at the productive, right side of the global leaf economics spectrum (Figs. 4, 5, 6). High photosynthetic capacity and high PNUE indeed confer a high productivity, as they are positively correlated with species growth rates (e.g., Poorter and Bongers 2006; Zhang and Cao 2009). Below, we discuss why Chinese savanna species are productive in terms of leaf structures, nutrient status and resource use efficiencies, and how they are adapted to drought.

\section{Productive structures}

A high photosynthetic performance of Chinese savanna species may partly be caused by their productive anatomical leaf structures. Chinese savanna species are characterized by a well-developed palisade mesophyll, as indicated by high ratio of palisade to spongy mesophyll (Table 1), which is associated with efficient capture and transmission of light into chloroplasts (Gibson 1998; Hanba et al. 1999). In addition, Chinese savanna species have high stomatal density (Table 1) compared to rainforest species (Grubb 1977; Bongers and Popma 1990). High stomatal density allows for a high supply of $\mathrm{CO}_{2}$ for assimilation (Tanaka and Shiraiwa 2009). Leaves with well-developed palisade mesophylls and high stomatal density are geared towards a fast gas exchange, which does not only imply high $\mathrm{CO}_{2}$ influx but also high $\mathrm{H}_{2} \mathrm{O}$ efflux. Such leaves generally have high leaf vein density, and thus greater hydraulic conductance (Sack and Frole 2006; Brodribb and Jordan 2011), thus favoring higher photosynthetic capacity.

Leaf density and/or leaf thickness may constrain photosynthetic capacity (e.g., Niinemets 1999, 2001) for two reasons: denser or thicker leaves may allocate a greater fraction of $\mathrm{N}$ to nonphotosynthetic tissues (Poorter and Evans 1998; Hikosaka and Hirose 2000; Pons and Westbeek 2004) and thick leaves may increase the path length for $\mathrm{CO}_{2}$ diffusion, whereas dense leaves may increase the resistance to $\mathrm{CO}_{2}$ diffusion (Niinemets 1999). Our results partly support 


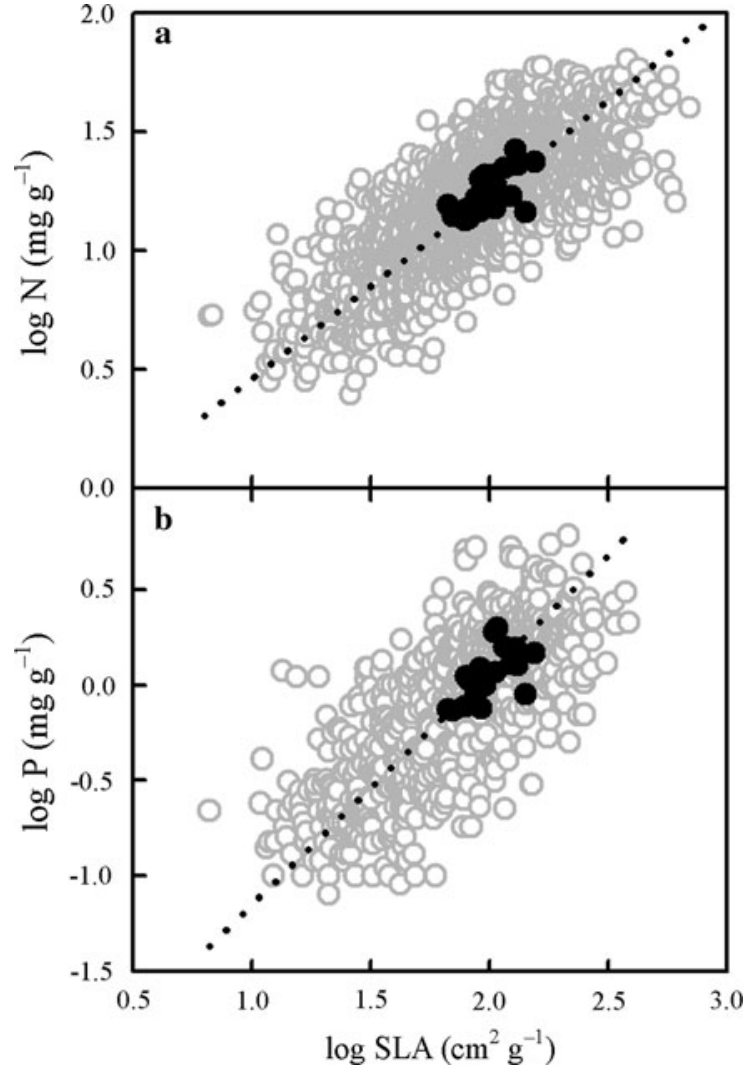

Fig. 4 Scatter plot of $\mathbf{a}$ foliar $\mathrm{N}$ and $\mathbf{b} \mathrm{P}$ with specific leaf area (SLA) for Chinese savanna species measured in this study (black cycles) and for all species from GLOPNET (gray cycles). Dotted lines are SMA regression lines for Chinese savanna and GLOPNET species. See Table 2 for regression statistics

these predictions. We indeed found that both leaf $\mathrm{N}$ and $A_{\mathrm{m}}$ decline with leaf thickness, although the slopes of these relationships are shallower than for other Australian savanna species (Fig. 3a, b), indicating that Chinese savanna species are less constrained by leaf thickness. However, both leaf $\mathrm{N}$ and $A_{\mathrm{m}}$ did not decline with leaf density across Chinese savanna species (Fig. 3c, d), whereas these negative relationships have been found across 597 woody species from a wide range of terrestrial biomes (Niinemets 1999) and across 23 Australian savanna species (Prior et al. 2003; also see Fig. 3). Possibly, Chinese savanna species can escape this constraint because they compensate for their high leaf density by having relatively thin leaves and high stomatal density (Table 1; Fig. 2). Summarizing, dense but thin leaves, in combination with well-developed palisade mesophylls, and high stomatal density all confer a high photosynthetic capacity of Chinese savanna species.

\section{Nutrient use efficiency}

Paradoxically, high resource use efficiencies can be associated with fast or slow growth; if resources are sufficient, then high resource use efficiency are often associated with high growth rate and high productivity; if resources are limited, then high resource use efficiency often means a more economic utilization of the few resources available, and less growth. In this study, PNUE was on average $22 \%$ higher and PPUE $15 \%$ higher compared to rainforest tree species (Table 1). In addition, the higher intercepts of Chinese savanna species for the regression lines relating $A_{\mathrm{m}}$ to $\mathrm{N}$ or $A_{\mathrm{m}}$ to $\mathrm{P}$, also indicate that Chinese savanna species have higher nutrient use efficiencies compared to the global dataset (Fig. 5; Table 2). As $\mathrm{N}$ does not limit photosynthesis for Chinese savanna species (see Table S5), a high PNUE may confer a high productivity. However, because of low $\mathrm{P}$ availability of Chinese savanna soils (Table S5), the high PPUE of Chinese savanna species (Table 1) could just be a long-term adaptation to soil $\mathrm{P}$ deficit in the valley-type savanna.

Chinese savanna species tend to use their water very efficiently; they have (1) similar intrinsic water use efficiency compared to rainforest species (Table 1), (2) higher $\delta^{13} \mathrm{C}$ than those from tropical rainforest in the same region (Qu et al. 2001) and those from other tropical savannas (Goldstein et al. 1989), indicating a higher long-term intrinsic water use efficiency, and (3) a significantly higher $A_{\mathrm{a}}$ for a given $g_{\text {s }}$ compared to a global dataset (Fig. 6). Since most species studied are deciduous (Table S2), high intrinsic water use efficiency could not be an adaptation to the dry season drought, but allow them to cope with atmospheric wet season water stress as a result of high irradiance and high (leaf) temperature. Despite their productive leaves, Chinese woody savanna species have a low stature (height). Perhaps one reason for this low stature is that Chinese savanna species photosynthesize - even during the favorable wet season-for a short period of the day because of stomatal closure induced by high light and temperature. Additionally, drought-induced shoot dieback may constrain plant height. 
Table 2 SMA regression slopes, intercepts and shifts along the common slopes for $\log -\log \operatorname{linear}$ relations among SLA, N, P, $A_{\mathrm{m}}, g_{\mathrm{s}}$, and $A_{\mathrm{a}}$ of Chinese savanna and GLOPNET species

\begin{tabular}{|c|c|c|c|c|c|c|}
\hline$y$ versus $x$ & Species groups & $n$ & $r^{2}$ & Slope & Intercept & Shifts along the common slope \\
\hline \multirow[t]{2}{*}{ Log $N$ vs. $\log$ SLA } & Chinese savanna & 21 & $0.40 * *$ & 0.78 & -0.33 & ns \\
\hline & GLOPNET & 1,958 & $0.57 * * *$ & & -0.32 & \\
\hline \multirow[t]{2}{*}{ Log P vs. $\log$ SLA } & Chinese savanna & 21 & $0.40 * *$ & 1.22 & -2.39 & $* * *$ \\
\hline & GLOPNET & 739 & $0.55 * * *$ & & -2.37 & \\
\hline \multirow[t]{2}{*}{$\log A_{\mathrm{m}}$ vs. $\log$ SLA } & Chinese savanna & 23 & $0.47 * * *$ & 1.33 & $-0.54 * * *$ & \\
\hline & GLOPNET & 764 & $0.50 * * *$ & & -0.65 & \\
\hline \multirow[t]{2}{*}{$\log A_{\mathrm{m}}$ vs. $\log \mathrm{N}$} & Chinese savanna & 17 & $0.37 * *$ & 1.71 & $-0.02 * * *$ & \\
\hline & GLOPNET & 712 & $0.53 * * *$ & & -0.14 & \\
\hline \multirow[t]{2}{*}{$\log A_{\mathrm{m}}$ vs. $\log \mathrm{P}$} & Chinese savanna & 17 & $0.61 * * *$ & 1.02 & $2.07 * * *$ & \\
\hline & GLOPNET & 212 & $0.16^{* * *}$ & & 1.92 & \\
\hline \multirow[t]{2}{*}{$\log A_{\mathrm{a}}$ vs. $\log g_{\mathrm{s}}$} & Chinese savanna & 24 & $0.51 * * *$ & 0.74 & $-0.62 * * *$ & \\
\hline & GLOPNET & 498 & $0.35 * * *$ & & -0.73 & \\
\hline
\end{tabular}

All traits were $\log _{10}$-transformed before analysis. Sample sizes $(n)$, coefficients of determination $\left(r^{2}\right)$, slopes, intercepts and shifts along the common slope of the SMA were reported

$A_{\mathrm{a}}$ maximum photosynthetic rate per area; $A_{\mathrm{m}}$ maximum photosynthetic rate per mass; $g_{\mathrm{s}}$ stomatal conductance; $S L A$ specific leaf area If the slopes were not significantly different between groups, then the common slopes were given; if no significant differences in slopes and shifts in intercepts were detected, shifts along the common slopes were then tested for $n s P>0.05$; ** $P<0.01$; *** $P<0.001$

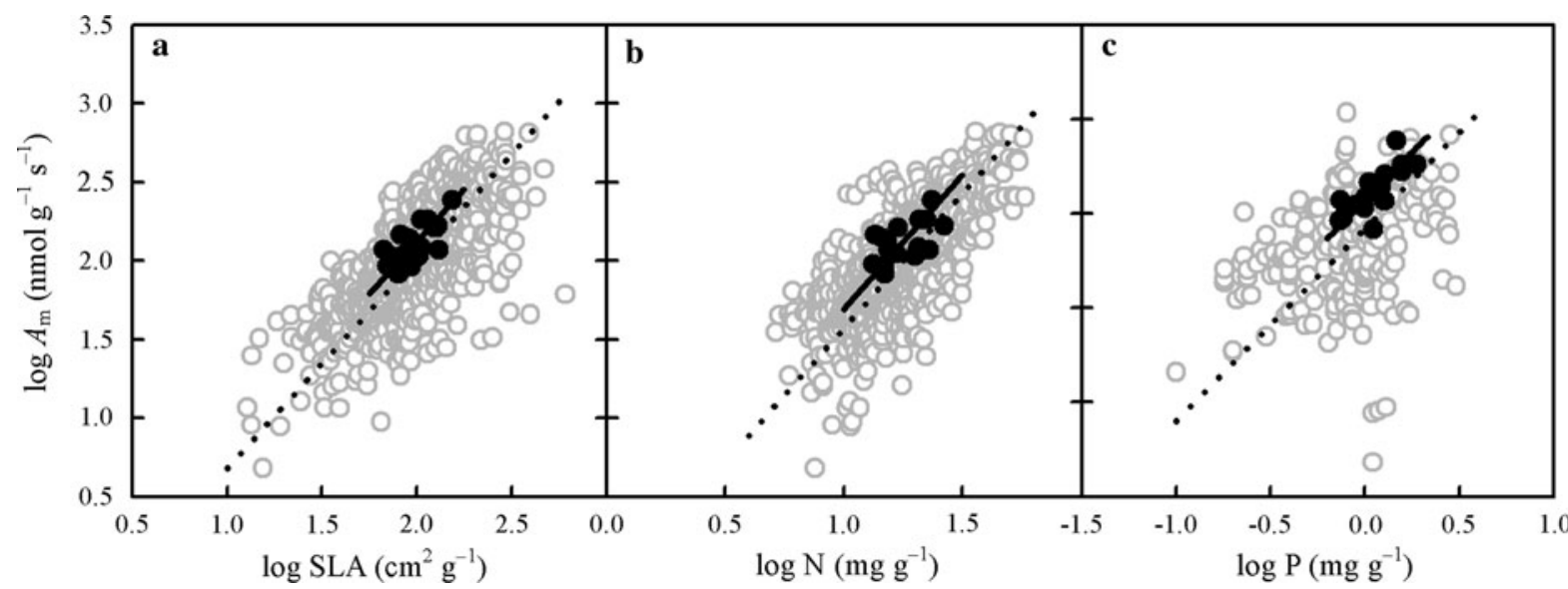

Fig. 5 Scatter plot of maximum photosynthetic rate per mass $\left(A_{\mathrm{m}}\right)$ with a specific leaf area (SLA), $\mathbf{b} \mathrm{N}$, and $\mathbf{c} \mathrm{P}$ concentrations for Chinese savanna species measured in this study (black cycles) and for all species from GLOPNET (gray cycles). Solid

Adaptation of productive species to drought

We hypothesized that Chinese savanna species are adapted to drought by having a drought-avoiding strategy that increases water uptake and/or reduces water loss. Chinese savanna species indeed show several drought avoidance adaptations. We found that evergreen species and some winter deciduous species and dotted lines were SMA regression lines for Chinese savanna species and GLOPNET species, respectively. See Table 2 for regression statistics

in Chinese savannas possess deep tap roots, which allow them to access deep soil water (Zhang et al. 2007). In contrast, most drought-deciduous species from Chinese savannas have a typical shallow root system but with very long lateral roots (usually 2-4 times longer than plant height), which allow them to absorb water from moist microsites and to recover more quickly after raining (Zhang et al. 2007). We 


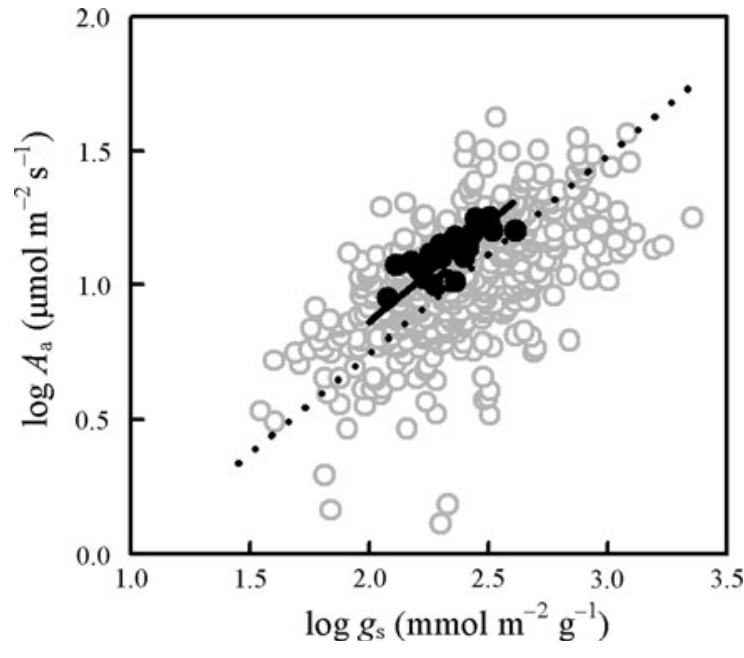

Fig. 6 Scatter plot of maximum photosynthetic rate per area $\left(A_{\mathrm{a}}\right)$ and stomatal conductance $\left(g_{\mathrm{s}}\right)$ for Chinese savanna species measured in this study (black cycles) and for all species from GLOPNET (gray cycles). Solid and dotted lines were SMA regression lines for Chinese savanna species and GLOPNET species, respectively. See Table 2 for regression statistics

hypothesized that Chinese savanna species would have small leaf area and thick cuticles to reduce transpirational demand and cuticular conductance, but surprisingly, Chinese savanna species turned to have similar leaf area and cuticle thickness compared to rainforest species (Table 1). In addition, our recent study showed that evergreen species, such as $C y$ clobalanopsis helferiana (Table S2), respond to drought by rapidly closing stomata and thus maintaining constant relative water content (Zhang et al. 2007), which is a typical drought avoidance strategy (e.g., Gulías et al. 2002). Leaf shedding is also an important phenological drought avoidance adaptation; winter deciduous species start to shed leaves from the beginning of the dry season when soil moisture is still quite high, whereas drought-deciduous species shed leaves in the late dry season when the water deficit is severe. Shoot dieback has been observed in droughtdeciduous species from Chinese savannas during prolonged drought (Zhang et al. 2007), probably due to hydraulic failure (e.g., Davis et al. 2002).

\section{Conclusions}

Paradoxically, we found that Chinese savanna species are adapted to the stressful hot- and seasonally dry valley habitat, by having productive leaves. High leaf productivity is brought about by a drought avoidance strategy, in combination with thin and dense leaves with high leaf nutrient concentrations, high nutrientand intrinsic water use efficiency, and high photosynthetic capacity.

Acknowledgments We thank the Biogeochemistry Laboratory of Xishuangbanna Tropical Botanical Garden for the analyses of soil and foliar nutrient concentrations and anonymous reviewers for helpful comments that significantly improved this manuscript. This study was supported by the National Natural Science Foundation of China $(30900174,90302013)$, and by West Light Foundation of Chinese Academy of Sciences to JLZ.

\section{References}

Balaguer L, Pugnaire FI, Martínez-Ferri E, Armas C, Valladares F, Manrique E (2002) Ecophysiological significance of chlorophyll loss and reduced photochemical efficiency under extreme aridity in Stipa tenacissima L. Plant Soil 240:343-352

Bongers F, Popma J (1990) Leaf characteristics of the tropical rain forest flora of Los Tuxtlas, Mexico. Bot Gazette 151: 354-365

Bowman DMJS, Prior LD (2005) Why do evergreen trees dominate the Australian seasonal tropics? Aust J Bot 53: 379-399

Brodribb TJ, Jordan GJ (2011) Water supply and demand remain balanced during leaf acclimation of Nothofagus cunninghamii trees. New Phytol 192:437-448

Clifford SC, Arndt SK, Corlett JE, Joshi S, Sankhla N, Popp M, Jones HG (1998) The role of solute accumulation, osmotic adjustment and changes in cell wall elasticity in drought tolerance in Ziziphus mauritiana (Lamk.). J Exp Bot 49: 967-977

Davis SD, Ewers FW, Sperry JS, Portwood KA, Crocker MC, Adams GC (2002) Shoot dieback during prolonged drought in Ceanothus (Rhamnaceae) chaparral of California: a possible case of hydraulic failure. Am J Bot 89:820-828

Eamus D, Prichard H (1998) A cost-benefit analysis of leaves of four Australian savanna species. Tree Physiol 18:537-545

Farquhar GD, Ehleringer JR, Hubick KT (1989) Carbon isotope discrimination and photosynthesis. Annu Rev Plant Physiol Plant Mol Biol 40:503-537

Gibson AC (1998) Photosynthetic organs of desert plants: structural designs of nonsucculent desert plants cast doubt on the popular view that saving water is the key strategy. Bioscience 48:911-920

Givnish TJ (2002) Adaptive significance of evergreen vs. deciduous leaves: solving the triple paradox. Silva Fennica 36:703-743

Goldstein G, Rada F, Rundel P, Azocar A, Orozco A (1989) Gas exchange and water relations of evergreen and deciduous tropical savanna trees. Ann Sci For 46(suppl.):448s-453s 
Grime JP (1977) Evidence for the existence of three primary strategies in plants and its relevance to ecological and evolutionary theory. Am Nat 111:1169-1194

Grime JP, Thompson K, Hunt R, Hodgson JG, Cornelissen JHC, Rorison IH, Hendry GAF, Ashenden TW, Askew AP, Band SR, Booth RE, Bossard CC, Campbell BD, Cooper JEL, Davison AW, Gupta PL, Hall W, Hand DW, Hannah MA, Hillier SH, Hodkinson DJ, Jalili A, Liu Z, Mackey JML, Matthews N, Mowforth MA, Meal AM, Reader RJ, Reiling K, Ross-Fraser W, Sutton F, Tasker DE, Thorpe PC, Whitehouse J (1997) Integrated screening validates primary axes of specialisation in plants. Oikos 79:259-281

Grubb PJ (1977) Control of forest growth and distribution on wet tropical mountains: with special reference to mineral distribution. Annu Rev Ecol Syst 8:83-107

Gulías J, Flexas J, Abadía A, Medrano H (2002) Photosynthetic responses to water deficit in six Mediterranean sclerophyll species: possible factors explaining the declining distribution of Rhamnus ludovici-salvatoris, an endemic Balearic species. Tree Physiol 22:687-697

Hanba YT, Miyazawa S-I, Terashima I (1999) The influence of leaf thickness on the $\mathrm{CO}_{2}$ transfer conductance and leaf stable carbon isotope ratio for some evergreen tree species in Japanese warm-temperate forests. Funct Ecol 13:632639

He J-S, Wang ZH, Wang XP, Schmid B, Zuo WY, Zhou M, Zheng CY, Wang M, Fang JY (2006) A test of the generality of leaf trait relationships on the Tibetan Plateau. New Phytol 170:835-848

Hikosaka K, Hirose T (2000) Photosynthetic nitrogen-use efficiency in evergreen broad-leaved woody species coexisting in a warm-temperate forest. Tree Physiol 20:12491254

IPCC (2007) Climate change 2007. Fourth assessment report of intergovernmental panel on climate change. Cambridge University Press, Cambridge

Jin ZZ, Ou XK (2000) Yuanjiang, Nujiang, Jinshajiang, Lancangjiang: vegetation of dry-hot valley. Yunnan University Press \& Yunnan Science and Technology Press, Kunming

Markesteijn L, Poorter L (2009) Seedling root morphology and biomass allocation of 62 tropical tree species in relation to drought- and shade-tolerance. J Ecol 97:311-325

Markesteijn L, Poorter L, Paz H, Sack L, Bongers F (2011) Ecological differentiation in xylem cavitation resistance is associated with stem and leaf structural traits. Plant Cell Environ 34:137-148

Niinemets Ü (1999) Components of leaf dry mass per areathickness and density-alter leaf photosynthetic capacity in reverse directions in woody plants. New Phytol 144: $35-57$

Niinemets Ü (2001) Global-scale climatic controls of leaf dry mass per area, density, and thickness in trees and shrubs. Ecology 82:453-469

Pons TL, Westbeek MHM (2004) Analysis of differences in photosynthetic nitrogen-use efficiency between four contrasting species. Physiol Plant 122:68-78

Poorter L, Bongers F (2006) Leaf traits are good predictors of plant performance across 53 rain forest species. Ecology $87: 1733-1743$
Poorter H, Evans JR (1998) Photosynthetic nitrogen-use efficiency of species that differ inherently in specific leaf area. Oecologia 116:26-37

Prior LD, Eamus D, Bowman DMJS (2003) Leaf attributes in the seasonally dry tropics: a comparison of four habitats in northern Australia. Funct Ecol 17:504-515

Qu C-M, Han X-G, Su B, Huang J-H, Jiang G-M (2001) The characteristics of foliar $\delta^{13} \mathrm{C}$ values of plants and plant water use efficiency indicated by $\delta^{13} \mathrm{C}$ values in two fragmented rainforests in Xishuangbanna, Yunnan. Acta Bot Sin 43:186-192

Reich PB, Walters MB, Ellsworth DS (1997) From tropics to tundra: global convergence in plant functioning. Proc Natl Acad Sci USA 94:13730-13734

Reich PB, Ellsworth DS, Walters MB, Vose JM, Gresham C, Volin JC, Bowman WD (1999) Generality of leaf trait relationships: a test across six biomes. Ecology 80: 1955-1969

Running SW, Nemani RR, Heinsch FA, Zhao M, Reeves M, Hashimoto H (2004) A continuous satellite-derived measure of global terrestrial primary production. Bioscience 54:547-560

Sack L, Frole K (2006) Leaf structural diversity is related to hydraulic capacity in tropical rain forest trees. Ecology 87:483-491

Sack L, Cowan PD, Jaikumar N, Holbrook NM (2003) The 'hydrology' of leaves: co-ordination of structure and function in temperate woody species. Plant Cell Environ 26:1343-1356

Tanaka Y, Shiraiwa T (2009) Stem growth habit affects leaf morphology and gas exchange traits in soybean. Ann Bot 104:1293-1299

Toledo M, Peña-Claros M, Bongers F, Alarcón A, Balcázar J, Chuviña J, Leaño C, Licona JC, Poorter L (2012) Distribution patterns of tropical woody species in response to climatic and edaphic gradients. J Ecol 100:253-263

Warman L, Moles AT, Edwards W (2011) Not so simple after all: searching for ecological advantages of compound leaves. Oikos 120:813-821

Warton DI, Wright IJ, Falster DS, Westoby M (2006) Bivariate line-fitting methods for allometry. Biol Rev 81:259-291

Wright IJ, Reich PB, Westoby M (2001) Strategy shifts in leaf physiology, structure and nutrient content between species of high- and low-rainfall and high- and low-nutrient habitats. Funct Ecol 15:423-434

Wright IJ, Reich PB, Westoby M, Ackerly DD, Baruch Z, Bongers F, Cavender-Bares J, Chapin T, Cornelissen JHC, Diemer M, Flexas J, Garnier E, Groom PK, Gulias J, Hikosaka K, Lamont BB, Lee T, Lee W, Lusk C, Midgley JJ, Navas M-L, Niinemets Ü, Oleksyn J, Osada N, Poorter H, Poot P, Prior L, Pyankov VI, Roumet C, Thomas SC, Tjoelker MG, Veneklaas EJ, Villar R (2004) The worldwide leaf economics spectrum. Nature 428:821-827

Wright IJ, Reich PB, Cornelissen JHC, Falster DS, Garnier E, Hikosaka K, Lamont BB, Lee W, Oleksyn J, Osada N, Poorter H, Villar R, Warton DI, Westoby M (2005) Assessing the generality of global leaf trait relationships. New Phytol 166:485-496

Wu ZY (1995) The vegetation of China. Science Press, Beijing Zhang JL, Cao KF (2009) Stem hydraulics mediates leaf water status, carbon gain, nutrient use efficiencies and plant 
growth rates across dipterocarp species. Funct Ecol 23: 658-667

Zhang JL, Zhu JJ, Cao KF (2007) Seasonal variation in photosynthesis in six woody species with different leaf phenology in a valley savanna in southwestern China. Trees 21: $631-643$
Zhu JJ, Zhang JL, Liu HC, Cao KF (2009) Photosynthesis, nonphotochemical pathways and activities of antioxidant enzymes in a resilient evergreen oak under different climatic conditions from a valley-savanna in Southwest China. Physiol Plant 135:62-72 